\title{
Sobre las etiquetas de género en tres películas de JODOROWSKY: Poesía sin fin, La Danza de la Realidad y Fando y Lis
}

El presente artículo es una reflexión sobre cómo se puede adjudicar un género cinematográfico o no a estas películas del cineasta Alejandro Jodorowsky, que abarcan tanto el inicio como lo último de su obra, sin considerar su documental Psychomagie, un art pour guérir del año 2019, aún no exhibido en el Perú. $\star$ José Carlos Cabrejo
En relación con la saga autobiográfica de Alejandro Jodorowsky compuesta por La Danza de la Realidad (2013) y Poesía sin fin (2016), podemos apreciar que son calificadas en la base de datos en línea IMDb (Internet Movie Database) bajo las etiquetas de género "biografía" y "fantasía", a partir de ciertas imágenes recurrentes. Aparece en la pantalla el propio Jodorowsky interpretándose a sí mismo o a otros actores interpretándolo de joven o niño. Por otra parte, suceden actos mágicos: los personajes, de pronto, pueden volverse invisibles y los objetos aparecen o desaparecen sobrenaturalmente. Un sitio web de cine como Filmaffinity no solo las califica bajo el rótulo de "biográfico" sino también bajo el calificativo de "surrealismo". En sentido estricto, hay que recordar que las películas calificadas como surrealistas apenas llegan a esa denominación debido al marco de la vanguardia en el que se desarrollaron, esencialmente Un perro andaluz (Un chien andalou, 1929) y La edad de oro (L'Âge d'Or, 1930) de Luis Buñuel; y no cabe el entendimiento del surrealismo como un género, más allá del halo surreal que uno suele encontrar en escenas del cine de Jodorowsky.

Con respecto a la biografía, Vincent Pinel (2009) destaca que este tipo de película "dedica lo esencial de su contenido a recrear la vida de un personaje famoso o ejemplar cuya existencia resulta acreditada por la historia o por la actualidad" (p. 45) y que en ella 


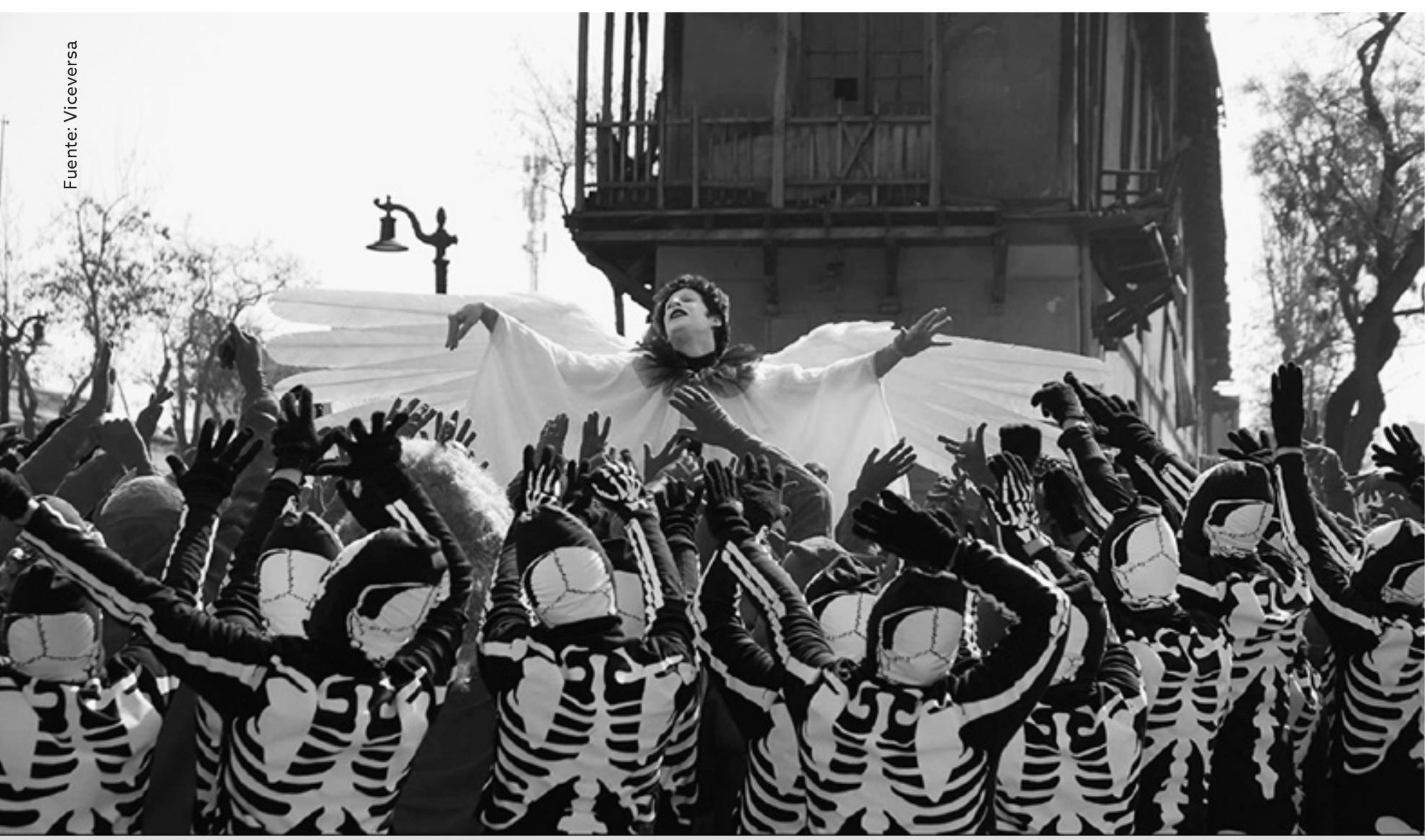

el resultado puede ser una biografía novelada —en el caso de que los aspectos más novelescos sean explotados-o bien una biografía hagiográfica, cuando el valor ejemplarizante constituye el elemento privilegiado. Pero el director también puede hacer prevalecer sus propias preocupaciones dramáticas, estéticas o pedagógicas. En suma, la película biográfica suele estar más influenciada por el retratista que por el propio modelo. (Pinel, 2009, p. 46)

Esa última descripción de la película biográfica es la que mejor encaja en las características de estos largometrajes de Jodorowsky, solo que los componentes fantásticos antes referidos alteran sus rasgos de "biopic" no solo por aproximarse a las imágenes propias del realismo mágico de la literatura latinoamericana, sino también por orientarse, más que a estructuras del género fantástico, a las características del cine moderno, con sus juegos temporales al estilo de algunas películas de Raúl Ruiz, o con sus recorridos espaciales y nostálgicos que apelan a la exageración pero también al final abierto, no conclusivo, en afinidad con Amarcord (1973) de Federico Fellini.

En estas entregas de Jodorowsky se aprecia al protagonista separándose de una tierra querida (Tocopilla) o de sus propios padres. En este último caso, que corresponde a Poesía sin fin, el padre de Alejandro (interpretado por Brontis Jodorowsky) se aleja de su apariencia vista en la película anterior: se le afeita el bigote de connotaciones stalinescas y el cabello, y viéndosele a continuación no solo como un monje budista, sino también como un sujeto que es reducido a su yo esencial, para apreciarlo unido a la inmensidad de mar, en el que el Jodorowsky joven, interpretado por Adán Jodorowsky, viaja hacia Francia en un final que, tal como ya lo indicamos, es abierto. Estos aspectos también alejan a dichas películas de las típicas cintas biográficas, en las que se aprecia finalmente qué ocurrió con el personaje retratado en una etapa concreta de su vida, algo que se puede notar tanto en un clásico de los primeros tiempos del cine sonoro como en El joven Lincoln (Young Mr. Lincoln, 1939), de John Ford, como en un filme de las últimas décadas como Ed Wood (1994) de Tim Burton. El Alejandro Jodorowsky retratado en estos filmes es, tal como lo diría Gérard Imbert (2010), un sujeto a la deriva, en constante tránsito, sin parada final (p. 266).

\section{Relato feérico}

Esa misma dinámica narrativa podemosidentificar en Fando y Lis (1968), que en términos de género es un filme más próximo a la estructura del cuento de hadas que a un género cinematográfico como tal. Es muy útil en ese sentido la obra Morfología del cuento de Vladimir Propp (2011) consagrada al estudio de los cuentos maravillosos. En ella, el teórico ruso plantea "estudiar los cuentos a partir de las funciones de los personajes" (p. 32). La opera prima de Jodorowsky guarda una profunda semejanza con el cuento de Hansely
Foto:

Poesía sin fin 
